\title{
Fabrication and Characterization of CuO-based Solar Cells
}

\author{
Hiroki Kidowaki, Takeo Oku, Tsuyoshi Akiyama, Atsushi Suzuki \\ Balachandran Jeyadevan \& Jhon Cuya \\ Department of Materials Science, The University of Shiga Prefecture \\ 2500 Hassaka, Hikone, Shiga 522-8533, Japan \\ E-mail: oku@mat.usp.ac.jp
}

$\begin{array}{lc}\text { Received: August 30, } 2011 & \text { Accepted: September 16, } 2011 \quad \text { Published: January, } 2012 \\ \text { doi:10.5539/jmsr.v1n1p138 } & \text { URL: http://dx.doi.org/10.5539/jmsr.v1n1p138 }\end{array}$

\begin{abstract}
Cuprous oxide $(\mathrm{CuO})$-based solar cells with fullerene $\left(\mathrm{C}_{60}\right)$ were fabricated on indium tin oxide (ITO) by a spin-coating method. The microstructure and cell performance of the solar cells with the $\mathrm{CuO} / \mathrm{C}_{60}$ structure was investigated. A photovoltaic device based on an $\mathrm{ITO} / \mathrm{CuO} / \mathrm{C}_{60}$ hererojunction structure fabricated by the spin-coating method provided short-circuit current density of $0.18 \mathrm{mAcm}^{-2}$ and open circuit voltage of $0.04 \mathrm{~V}$ under illumination. The crystal structure of the $\mathrm{CuO}$ active layer was examined by using X-ray diffraction. The energy levels of the present solar cells are also discussed.
\end{abstract}

Keywords: Solar cell, Copper oxide, Photovoltaic property, Optical property

\section{Introduction}

Solar cell technology for future energy resources has been progressed recently. Silicon is used as the semiconductor material for conventional solar cells, and the cost reduction of the solar cells is one of the most important issues. $\mathrm{Cu}$ oxides such as $\mathrm{CuO}$ and $\mathrm{Cu}_{2} \mathrm{O}$ are one of the candidate materials. The features of copper oxide semiconductors are high optical absorption and nontoxic and low cost fabrication (Olsen, Bohara \& Urie, 1997; Herion, Niekisch \& Schari, 1980). $\mathrm{CuO}$ and $\mathrm{Cu}_{2} \mathrm{O}$ are p-type semiconductors with band gaps of $\sim 1.5 \mathrm{eV}$ and $\sim 2.0 \mathrm{eV}$, respectively, which are close to the ideal energy gap for solar cells and allows for good solar spectral absorption due to these direct band gap. The highest efficiency of $\sim 2 \%$ for $\mathrm{Cu}_{2} \mathrm{O}$ solar cells has been obtained by using the high-temperature annealing method and an expensive vacuum evaporation technique (Mittiga et al., 2006). Effcient hetero-junction solar cells with $\mathrm{p}-\mathrm{Cu}_{2} \mathrm{O}$ and $\mathrm{n}-\mathrm{ZnO}$ fabricated by electro-deposition and photochemical deposition methods have been investigated and reported (Izaki et al., 2006; Izaki et al., 2007).

The purpose of the present work is to fabricate and characterize solar cells with $\mathrm{CuO} / \mathrm{C}_{60}$ structures. Fullerene $\left(\mathrm{C}_{60}\right)$ is a good electron acceptor, and has been used as the n-type semiconductor active layer for organic cells (Jeong et al., 2007; Takeda et al., 2009).

\section{Experimental procedures}

$3.6 \mathrm{~g}$ of copper acetate and $30 \mathrm{~g}$ of oleylamine were introduced in $70 \mathrm{~g}$ of 1-heptanol. The solution was heated at $100{ }^{\circ} \mathrm{C}$ for 2 hours. Then, a hot 1-heptanol solution containing $1.9 \mathrm{~g}$ of $\mathrm{NaOH}$ was quickly added. After $2 \mathrm{~h}$ of reaction, the solution was cooled down to $25^{\circ} \mathrm{C}$. Throughout the process, the reaction system was subjected to mechanical stirring and purged with $\mathrm{N}_{2}$. At the end of the reaction, the particles were collected by centrifugation and washed several times with a mixture of toluene and methanol. Finally, $\mathrm{CuO}$ particles were dispersed in toluene.

A thin layer of polyethylenedioxythiophen doped with polystyrene-sulfonic acid (PEDOT:PSS) (Sigma Aldrich) was spin-coated at $2000 \mathrm{rpm}$ on pre-cleaned indium tin oxide (ITO) glass plates (Geomatec Co., Ltd., $\sim 10 \Omega / \square$ ). After annealing at $100^{\circ} \mathrm{C}$ for $10 \mathrm{~min}$ in $\mathrm{N}_{2}$ atmosphere, $\mathrm{CuO}$ layer was spin-coated at $1000 \mathrm{rpm}$. After annealing at $100{ }^{\circ} \mathrm{C}$ for $30 \mathrm{~min}$ in $\mathrm{N}_{2}$ atmosphere, $\mathrm{C}_{60}$ layer was spin-coated at $1000 \mathrm{rpm}$. After annealing at $100{ }^{\circ} \mathrm{C}$ for 30 min in $\mathrm{N}_{2}$ atmosphere, aluminium (Al) metal contacts with a thickness of $\sim 100 \mathrm{~nm}$ were deposited as top electrodes by using vacuum evaporation, and annealed at $140{ }^{\circ} \mathrm{C}$ for $20 \mathrm{~min}$ in $\mathrm{N}_{2}$ atmosphere. The solar cells were fabricated as a stacking structure of ITO/PEDOT:PSS $/ \mathrm{CuO} / \mathrm{C}_{60} / \mathrm{Al}$. Schematic illustration of the present solar cells is shown in Fig. 1. 
The current density-voltage (J-V) characteristics (Hokuto Denko Corp., HSV-100) of the solar cells were measured both in the dark and under illumination at $100 \mathrm{~mW} / \mathrm{cm}^{2}$ by using an AM 1.5 solar simulator (San-ei Electric, XES-301S) in $\mathrm{N}_{2}$ atmosphere. The solar cells were illuminated through the side of the ITO substrates, and the illuminated area measured $0.16 \mathrm{~cm}^{2}$. Optical absorption of the solar cells was investigated by means of UV-visible spectroscopy (Hitachi, Ltd., U-4100). The crystal structures, phases and crystallite sizes of the copper oxide and $\mathrm{C}_{60}$ thin film were investigated by wide X-ray diffractometer (XRD, PHILIPS X'Pert-MPD System) with $\mathrm{CuK} \alpha$ radiation operating at $40 \mathrm{kV}$ and $40 \mathrm{~mA}$.

\section{Results and discussion}

A solar cell with a $\mathrm{CuO} / \mathrm{C}_{60}$ structure provided power conversion efficiency $(\eta)$ of $1.8 \times 10^{-6} \%$, fill factor (FF) of 0.25 , short-circuit current density $\left(\mathrm{J}_{\mathrm{sc}}\right)$ of $0.18 \times 10^{-3} \mathrm{mAcm}^{-2}$ and open-circuit voltage $\left(\mathrm{V}_{\mathrm{oc}}\right)$ of $0.04 \mathrm{~V}$. The photocurrent was observed under illumination and the $\mathrm{CuO} / \mathrm{C}_{60}$ structure showed characteristic curves with short-circuit current and open-circuit voltage. Figure 2 shows measured optical absorption of thin films. The heterojunction and bulk heterojunction solar cells were denoted as $\mathrm{CuO} / \mathrm{C}_{60}$ and $\mathrm{CuO}: \mathrm{C}_{60}$, respectively. Individual $\mathrm{CuO}$ and $\mathrm{C}_{60}$ thin films were also measured. $\mathrm{The} \mathrm{CuO} / \mathrm{C}_{60}$ structure shows high optical absorption in the range of $400 \mathrm{~nm}$ and $800 \mathrm{~nm}$.

Transmittance spectrum of $100 \mathrm{~nm}$ thick $\mathrm{CuO}$ film, deposited on ITO, is presented in Fig. 3(a). From this spectrum, the optical absorption coefficients $(\alpha)$ of this film was determined from the spectral transmittance using the next equation, $\alpha=1 / \mathrm{d} \cdot \ln (1 / \mathrm{T})$. Where $\mathrm{d}$ is the film thickness and $\mathrm{T}$ is the transmittance (Jhin-Wei Chen et al., 2011). For determination of the optical band gap energy $\left(E_{g}\right)$, the method based on the relation of $\alpha \mathrm{h} v=$ $\mathrm{A}\left(\mathrm{h} v-\mathrm{E}_{\mathrm{g}}\right)^{\mathrm{n} / 2}$ was used, where $\mathrm{n}$ is a number that depends on the nature of the transition. In this case its value was found to be 1 (which corresponds to direct band to band transition).

Figure 3(b) is a Tauc plot, which shows $(\alpha h v)^{2}$ versus $\mathrm{h} v$ for the $\mathrm{CuO}$ film. The intersection of the straight line with the $h v$-axis determines the optical band gap energy $E_{g}$ (Georgieva \& Ristov, 2002). It was found to be about $3.7 \mathrm{eV}$ which is higher than the ideal band gap of the $\mathrm{CuO}$ crystal. Because of the large band gap energy, the short-circuit current density would be low.

All the crystalline components in the $\mathrm{CuO}$ and $\mathrm{C}_{60}$ thin films were investigated by $\mathrm{XRD}$, as shown in Fig. 4 . Diffraction peaks corresponding to $\mathrm{CuO}$ and $\mathrm{C}_{60}$ are observed in thin films, which consisted of cupric phase with monoclinic system (space group of $\mathrm{C} 2 / \mathrm{c}$ and lattice parameter of $\mathrm{a}=0.4653 \mathrm{~nm}, \mathrm{~b}=0.3410 \mathrm{~nm}, \mathrm{c}=0.5018 \mathrm{~nm}$, $\beta=99.481^{\circ}$ ). The particle size was estimated using Scherrer's equation: $D=0.9 \lambda / B \cos \theta$, where $\lambda$, $B$, and $\theta$ represent the wavelength of the X-ray source, the full width at half maximum (FWHM), and the Bragg angle, respectively (Oku et al., 2010). The crystallite sizes of $\mathrm{CuO}$ and $\mathrm{C}_{60}$ were determined to be $3.4 \mathrm{~nm}$ and $51.9 \mathrm{~nm}$, respectively. To increase the efficiency of the $\mathrm{CuO} / \mathrm{C}_{60}$ solar cell, small grain size of $\mathrm{C}_{60}$ and higher crystallinity of $\mathrm{CuO}$ would be necessary.

Energy level diagram of the $\mathrm{CuO} / \mathrm{C}_{60}$ solar cell is summarized as shown in Fig. 5. Previously reported values were used for the energy levels (Oku et al., 2010; Oku et al., 2011). It has been reported that $\mathrm{V}_{\text {oc }}$ is nearly proportional to the band gap of the semiconductors, and control of the energy level is important to increase efficiency (Park et al., 2010). Compared to silicon with an indirect transition band structure, $\mathrm{CuO}$ with a direct transition band structure is more suitable for the optical absorption property. In addition, the ultrathin film of the $\mathrm{CuO}$ layers could provide efficient charge injection because of the high optical absorption. Although $\mathrm{ZnO}$ has been mainly used as an n-type oxide semiconductor for solar cells (Motoyoshi et al., 2010), $\mathrm{C}_{60}$ was applied instead of $\mathrm{ZnO}$ in the present work.

The advantage of the present $\mathrm{C}_{60}$ is a good acceptor material for solar cells and the simple film formation using a spin-coating method. Compared to previously reported $\mathrm{CuO}$-based heterojunction solar cells prepared by a spin-coating method without a vacuum system were investigated in the present work. The low conversion efficiency of the present solar cells would be due to presence of $\mathrm{CuO}$ nanoparticle aggregation in the active layer.

\section{Conclusions}

ITO/PEDOT: $\mathrm{PSS} / \mathrm{CuO} / \mathrm{C}_{60} / \mathrm{Al}$ solar cells were produced and characterized, which provided $\eta$ of $1.8 \times 10^{-6} \%$, FF of $0.25, \mathrm{~J}_{\mathrm{sc}}$ of $0.18 \times 10^{-3} \mathrm{mAcm}^{-2}$ and $\mathrm{V}_{\text {oc }}$ of $0.04 \mathrm{~V}$. The $\mathrm{CuO} / \mathrm{C}_{60}$ structure showed high optical absorption in the range of $400 \mathrm{~nm}$ and $800 \mathrm{~nm}$, and the $\mathrm{E}_{\mathrm{g}}$ of $\mathrm{CuO}$ was found to be $\sim 3.7 \mathrm{eV}$ from the Tauc plot, which is higher than the ideal band gap of the $\mathrm{CuO}$ crystal and the short-circuit current density would be decreased. A crystallite size of $\mathrm{CuO}$ was determined to be $3.4 \mathrm{~nm}$, and higher crystallinity of $\mathrm{CuO}$ would increase the efficiency of the $\mathrm{CuO} / \mathrm{C}_{60}$ solar cells. The energy level of the present solar cell was proposed, and separated holes could transfer from the valence band of the $\mathrm{CuO}$ to the ITO, and separated electrons could transfer from the conduction band of 
the $\mathrm{CuO}$ to the $\mathrm{Al}$ electrode, respectively. Formation of the $\mathrm{CuO} / \mathrm{C}_{60}$ active layer with homogeneous distributed $\mathrm{CuO}$ nanopaticles would improve the efficiencies of the solar cells.

\section{References}

A. Mittiga, E. Salsa, F. Sarto, M. Tucci, \& R. Vasanthi. (2006). Applied. Physics. Letters, 88, 163502-163503. http://dx.doi.org/10.1063/1.2194315

A. Takeda, T. Oku, A. Suzuki, K. Kikuchi, \& S. Kikuchi. (2009). Fabrication and characterization of inorganic-organic hybrid solar cells based on CuInS 2 . Journal of the Ceramic Society of Japan, 117, 967-969.

J. Herion, E. A. Niekisch, \& G. Schari. (1980). Investigation of metal oxide/cuprous oxide heterojunction solar cells. Solar Energy Materials \& Solar Cells, 4, 101-112. http://dx.doi.org/10.1016/0165-1633(80)90022-2

J. W. Chen, D. C. Perng, \& J. F. Fang. (2011). Nano-structured $\mathrm{Cu}_{2} \mathrm{O}$ solar cells fabricated on sparse $\mathrm{ZnO}$ nanorods. Solar Energy Materials \& Solar Cells, 95, 2471-2477. http://dx.doi.org/10.1016/j.solmat.2011.04.034

L. C. Olsen, R. C Bohara, \& M. W. Urie. (1979). Explanation for low-effciency $\mathrm{Cu}_{2} \mathrm{O}$ Schottky-barrier solar cells. Applied Physics Letters, 34, 47-50. http://dx.doi.org/10.1063/1.90593

M. Izaki, K. Mizuno, T. Shinagawa, M. Inaba, \& A. Tasaka. (2006). Photochemical construction of photovoltaic device composed of p-copper (I) and n-zinc oxide. Journal of Electrochemical Society, 153, C668-C672. http://dx.doi.org/ 10.1149/1.2218791

M. Izaki, T. Shinagawa, K. Mizuno, Y Ida, M. Inaba, \& A. Tasaka. (2007). Photochemically constructed p- $\mathrm{Cu}_{2} \mathrm{O} / \mathrm{n}-\mathrm{ZnO}$ heterojunction diode device. Journal of Physics D: Applied Physics, 40, 3326-3329. http://dx.doi.org/10.1088/0022-3727/40/11/010

N. G. Park, M. G. Kang, K. S. Ryu, K. M. Kim, \& S. H. Chang. (2010). Photovoltaic characteristics of dye-sensitized surface-modified nanocrystalline $\mathrm{SnO}_{2}$ solar cells. Journal of Photochemistry and Photobiology A: Chemistry, 161, 105-110. http://dx.doi.org/10.1016/S1010-6030(03)00280-6

R. Motoyoshi, T. Oku, A. Suzuki, K. Kikuchi, S.Kikuchi, B. Jeyadevan, \& J. Cuya. (2010). Fabrication and characterization of cuprous oxide: fullerene solar cells. Synthetic Metals, 160, 1219-1222. http://dx.doi.org/doi:10.1016/j.synthmet.2010.03.012

S.S. Jeong, A. Mittiga, E. Salza, A. Masci, \& S. Passerini. (2008). Electrodeposited $\mathrm{ZnO} / \mathrm{Cu}_{2} \mathrm{O}$ heterojunction solar cells. Electrochem Acta, 53, 2226-2231. http://dx.doi.org/10.1016/j.electacta. 2007.09.030

T. Oku, R. Motoyoshi, K. Fujimoto, T. Akiyama, B. Jeyadevan, \& J. Cuya. (2011). Structures and photovoltaic properties of copper oxides/fullerene solar cells. Journal of Physics and Chemistry of Solids, 72, 1206-1211. http://dx.doi.org/doi:10.1016/j.jpcs.2011.06.014

T. Oku, T. Noma, A. Suzuki, K. Kikuchi, \& S. Kikuchi. (2010). Fabrication and characterization of fullerene/porphyrin bulk heterojunction solar cells. Journal of Physics and Chemistry of Solids, 71, 551-555. http://dx.doi.org/10.1016/j.jpcs.2009.12.034

V. Georgieva, \& M. Ristov. (2002). Electrodeposited cuprous oxide on indium tin oxide for solar applications. Solar Energy Materials \& Solar Cells, 73, 67-73. http://dx.doi.org/10.1016/S0927-0248(01)00112-X 


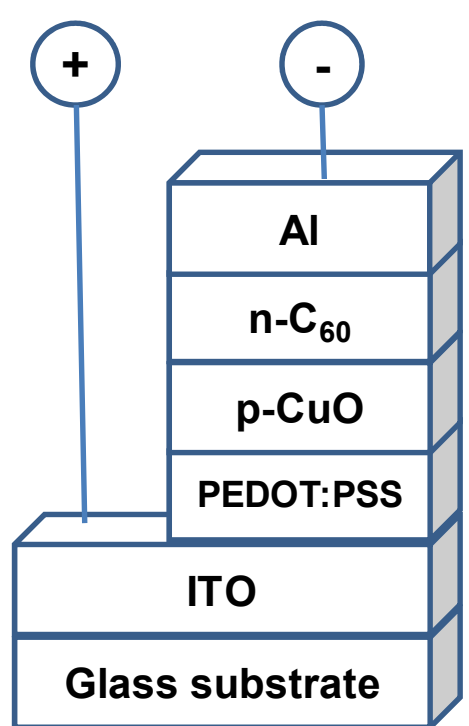

Figure 1. Schematic structure of $\mathrm{CuO}: \mathrm{C}_{60}$ heterojunction solar cells

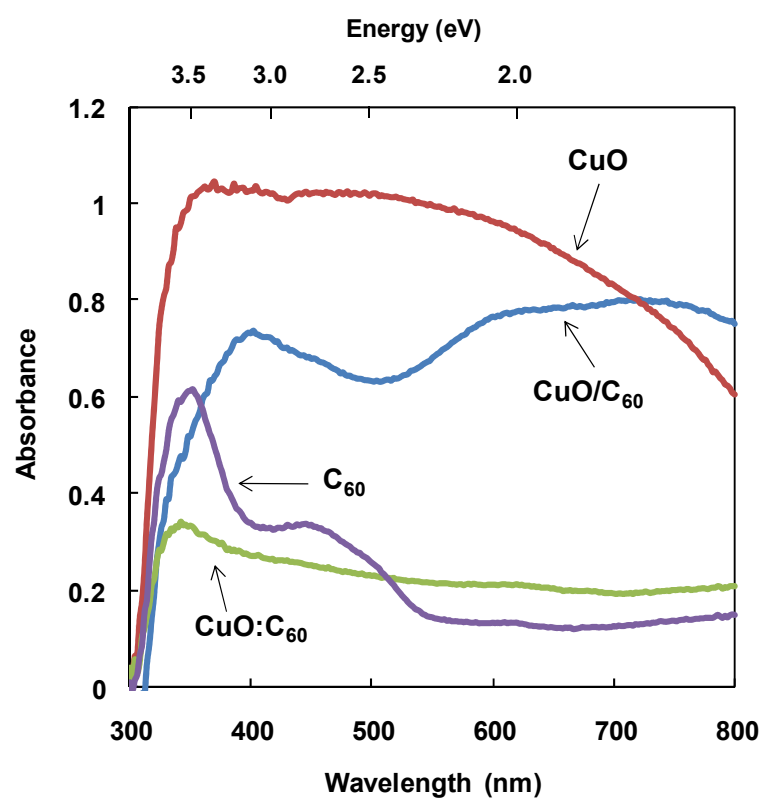

Figure 2. UV-visible absorption spectra of thin films 
(a)

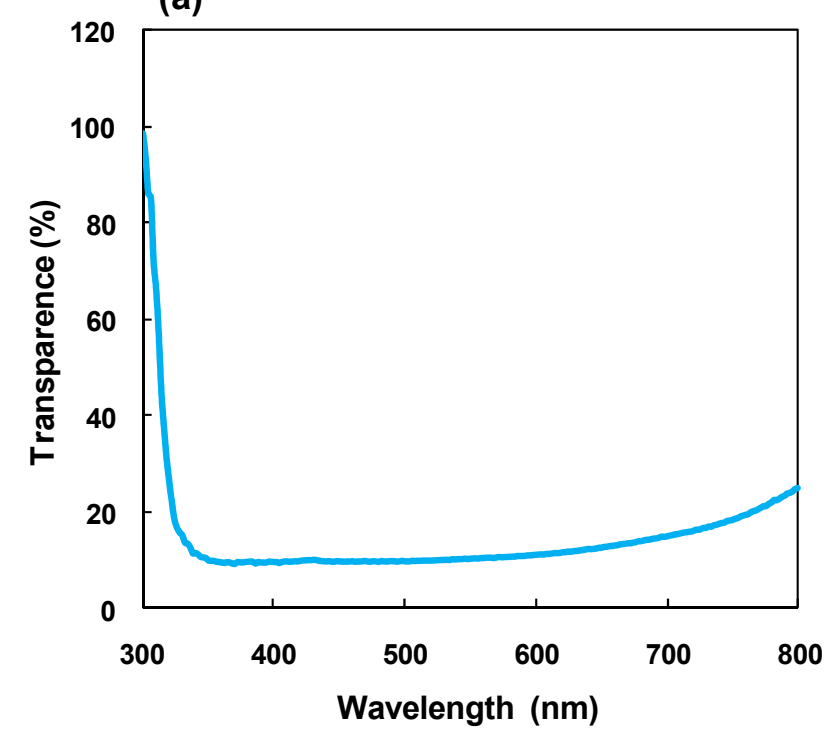

(b)

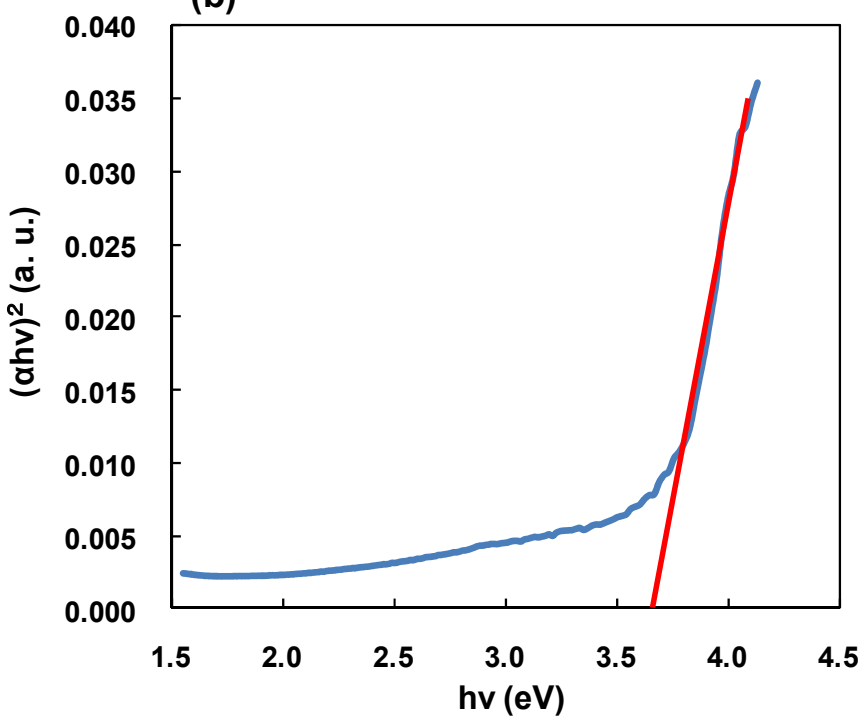

Figure 3. (a) Optical transmission spectrum of $100 \mathrm{~nm}$ thick $\mathrm{CuO}$ film, and (b) Tauc plot for the $\mathrm{CuO}$ thin film 
(a)

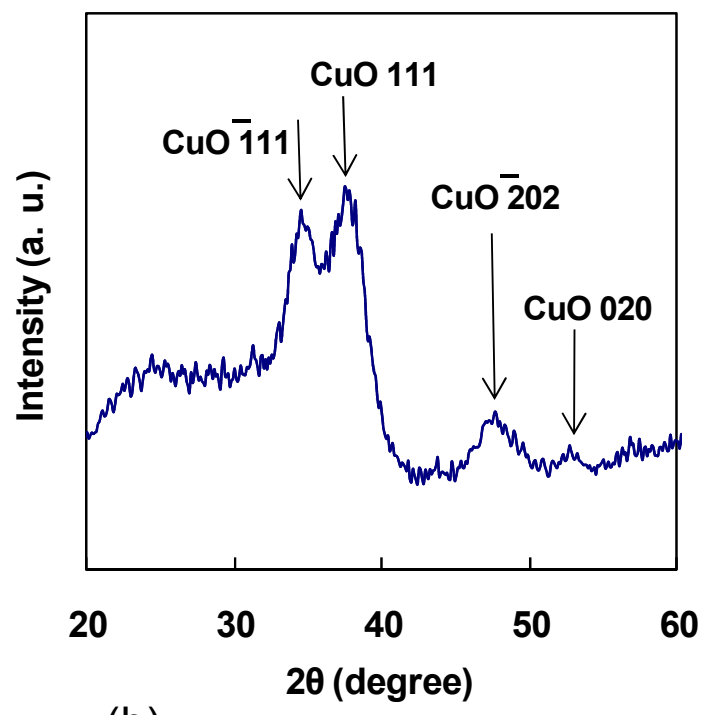

(b)

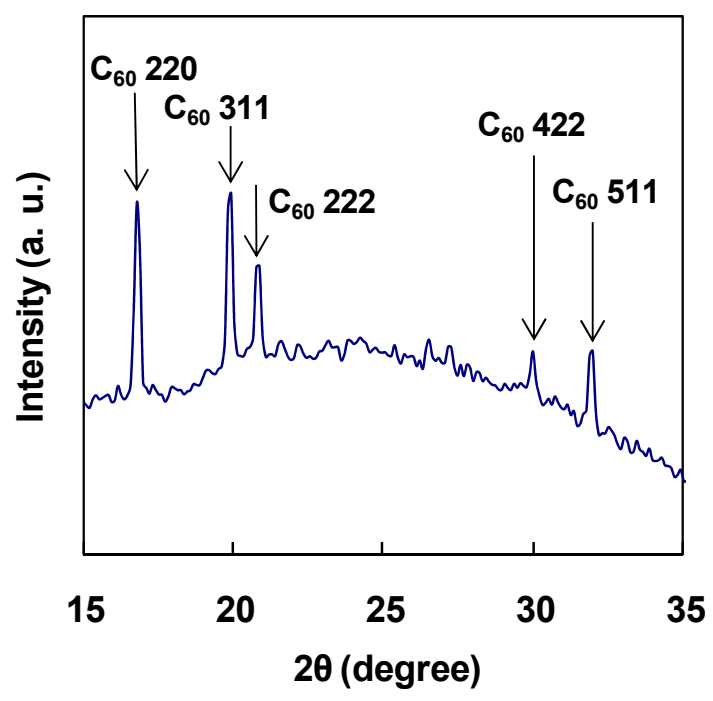

Figure 4. X-ray diffraction pattern of (a) $\mathrm{CuO}$ and (b) $\mathrm{C}_{60}$ thin films

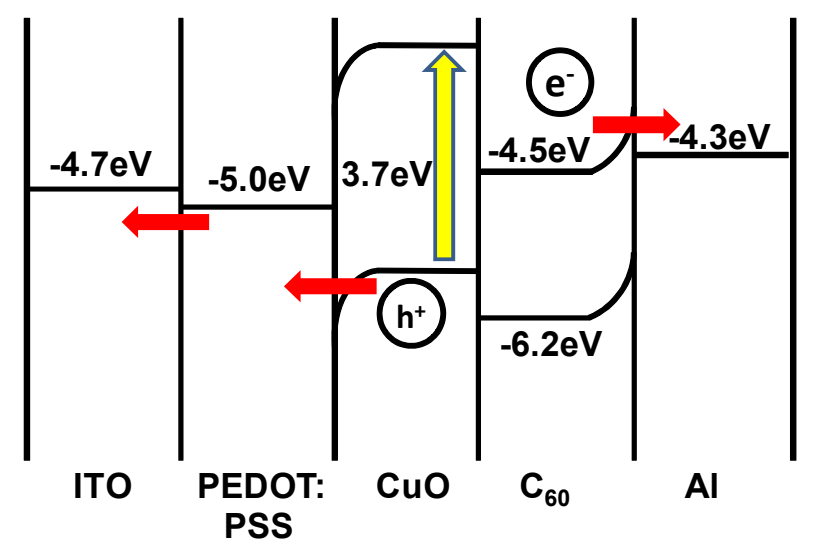

Figure 5. Energy level diagram of ITO/PEDOT: $\mathrm{PSS} / \mathrm{CuO} / \mathrm{C}_{60} / \mathrm{Al}$ solar cells 